PSYCHOLOGIA ROZWOJOWA, $2018 *$ tom 23 , nr 2, s. $67-84$

doi:10.4467/20843879PR.18.011.8945

www.ejournals.eu/Psychologia-Rozwojowa

EWA ZASĘPA

Zakład Psychologii Klinicznej Dzieci i Młodzieży, Instytut Psychologii,

Akademia Pedagogiki Specjalnej, Warszawa

Department of Clinical Psychology of Children and Adolescents, Institute of Psychology,

The Maria Grzegorzewska University, Warsaw

e-mail: zasepa@aps.edu.pl

\title{
Jakość życia rodziny a jakość życia młodych dorosłych z lekką niepełnosprawnością intelektualną
}

\author{
Family Quality of Life and Quality of Life of Young Adults \\ with Mild Intellectual Disability
}

\begin{abstract}
The aim of the present study was to find a relationship between the family quality of life and the quality of life of young adults with intellectual disability. 27 individuals with a mild intellectual disability were examined: 14 men and 13 women. Their average age was $M=18.89$ $(S D=1.25)$. The family quality of life was assessed by the subjects' mothers. In the study were also used the Family Quality of Life Survey - general version (FQoLS-2006) and the Quality of Life Profile. The research results demonstrated that two general indicators of the family quality of life reached values slightly below average: general assessment and general satisfaction. The domains of family quality of life which were rated best included: Family relationships, Health of the family, and Spiritual and cultural beliefs, while the lowest rates were attributed to Support from other people, Support from disability-related services, and Financial well-being. Young adults with mild intellectual disability have evaluated the quality of their lives as high. The positive associations were found between the family quality of life and the quality of life of young adults with mild intellectual disability.
\end{abstract}

Keywords: quality of life, family quality of life, intellectual disability.

Słowa kluczowe: jakość życia, jakość życia rodziny, niepełnosprawność intelektualna.

\section{WPROWADZENIE}

Celem przedstawionych w artykule badań jest poszukiwanie zależności między jakością życia rodziny, w której żyje osoba z niepełnosprawnością intelektualną wchodząca w dorosłość, a subiektywnie ocenioną jakością jej życia. Wyniki prac empirycznych (Čagran, Schmidt, Brown, 2011) oraz obserwacje społeczne wskazują na to, że większość osób z niepełnosprawnością intelektualną, nawet w wieku dorosłym, mieszka w domu rodzinnym z rodzicami, rodzeństwem lub innymi bliskimi krewnymi.
Rodzina pochodzenia ma więc w życiu osób $\mathrm{z}$ niepełnosprawnością intelektualną istotne znaczenie. Ważne wydaje się określenie, czy i w jaki sposób jakość życia całej rodziny, na którą składają się zarówno pozytywne doświadczenia, jak i troski wszystkich jej członków i rodziny jako całości, wpływa na subiektywną jakość życia samej osoby niepełnosprawnej.

Przed przystąpieniem do opisu badań zostaną wyjaśnione podstawowe pojęcia użyte w tekście, czyli jakość życia osób z niepełnosprawnością intelektualną oraz jakość życia rodziny. Omówione zostaną też wyniki stosun- 
kowo nielicznych badań dotyczących poruszanego zagadnienia.

\section{Jakość życia osób niepelnosprawnych intelektualnie}

Naukowe opracowania dotyczące jakości życia osób z niepełnosprawnością intelektualną mają swój początek w latach 70. XX wieku (Schwartz, Rabinovitz, 2003). Głębsze zainteresowanie tą problematyką jest wyrazem szacunku i podmiotowego traktowania osób niepełnosprawnych. Zwłaszcza istotne wydaje się ujmowanie subiektywnej perspektywy tych osób, które mają szansę powiedzieć o swoich potrzebach, troskach, celach życiowych oraz o doświadczanych trudnościach. Jest to ważne zarówno dla naukowych opracowań zmierzających ku lepszemu zrozumieniu osób z niepełnosprawnością intelektualną, jak i dla praktycznych oddziaływań mających na celu opracowanie programów wsparcia.

Kwestiami jakości życia omawianej populacji zajmują się utworzone specjalne międzynarodowe grupy z najbardziej znaną Special Interest Research Group on Quality of Life (SIRGQL), działającą przy Międzynarodowym Towarzystwie Naukowych Badań Niepełnosprawności Intelektualnej (International Association for the Scientific Study of Intellectual Disabilities, IASSID). Podstawowe założenia wypracowane przez specjalistów skupionych w SIRGQL są nastepujace: konstrukt ten ma charakter wielowymiarowy. Różnorodne dziedziny jakości życia ważne dla osób z generalnej populacji są również ważne, choć w różnym stopniu, dla osób niepełnosprawnych intelektualnie. Ważność poszczególnych dziedzin może się zmieniać w biegu życia. Konstrukt ten jest rozpatrywany z hierarchicznej perspektywy. Określając jakość życia osób z niepełnosprawnością intelektualną, należy mieć na względzie zarówno subiektywne, jak i obiektywne jej aspekty. Z tym, iż za ważniejszą należy uznać subiektywną percepcję osoby i jej odczucia odnośnie do jakości swojego życia. Jakość życia osoby niepełnosprawnej intelektualnie należy rozpatrywać, biorąc pod uwagę jej indywidualne cechy oraz czynniki środowiskowe. Podczas pomiaru tego konstruktu należy zadawać pytania zamknięte i otwarte. Dane dotyczące jakości życia powinny służyć lepszemu zrozumieniu potrzeb osób niepełnosprawnych oraz poprawie ich życia. Według Roberta Schalocka (2000, s. 118) bowiem ,jakość życia jest doświadczana, gdy podstawowe potrzeby są zaspokojone i gdy ma ona te same możliwości jak inni do ustanowienia i osiągnięcia celów w większości sytuacji w domu, społeczności, pracy”. Pojęcie jakości życia wiąże się z polityką społeczną i różnego rodzaju usługami oraz programami i inicjatywami o różnym zasięgu. Innymi słowy, wyniki dotyczące jakości życia osób z niepełnosprawnością intelektualną są i powinny być stosowane w tworzeniu programów wsparcia dla tych osób (Keith, Bonham, 2005; Schalock, 2000).

Warto się skupić przez chwilę na samym rozumieniu i definicjach jakości życia osób niepełnosprawnych. Według Schalocka i współpracowników (2002) definicje jakości życia osób $\mathrm{z}$ niepełnosprawnością intelektualną zawierają trzy główne elementy: ogólne poczucie dobrostanu, poczucie pozytywnego zaangażowania w aktywności społeczne i relacje interpersonalne oraz możliwości do rozwinięcia swoich potencjalności. Ich trafność potwierdzają badania empiryczne (np. Bramston, Chipuer, Pretty, 2005). Schalock (1994, s. 121) odnosił się do jakości życia jako „konceptu, który odzwierciedla kondycję życiową osoby”. Następnie (Schalock, 2000; Schalock i in., 2005) nieco zmodyfikował swój pogląd uznając, że: ,[j]akość życia jest koncepcją, która odzwierciedla kondycję życiową osoby posiadaną w zakresie następujących wymiarów: dobrostan emocjonalny, stosunki interpersonalne, dobrostan materialny, rozwój osobisty, dobrostan fizyczny, autonomia, integracja społeczna i prawa jednostki" (Schalock i in., 2005, s. 299). Rozumienie jakości życia osób niepełnosprawnych może zostać przybliżone przez wskazanie dziedzin objętych tym terminem. Grupa SIRGQL stwierdziła, iż najczęściej badacze wyodrębniają dziedziny związane z dobrostanem: 1) fizycznym, 2) emocjonalnym, 3) społecznym, 4) produktywnym, 5) materialnym i 6) cywilnym.

Poza określeniami tego konstruktu w literaturze przedmiotu można spotkać również koncep- 
cje oraz modele wyjaśniające go. Do najbardziej znanych można zaliczyć następujące: model jakości życia opracowany w paradygmacie systemowo-ekologicznym przez Roberta Schalocka i współpracowników (Schalock, 1994, 2000, 2004; Buntinx, Schalock, 2010), wielowymiarowy i wielopłaszczyznowy model jakości życia Roberta Cumminsa $(2001,2005)$ oraz model jakości życia Ivana Browna i współpracowników z Centrum Promocji Zdrowia w Toronto. Ponieważ w niniejszym tekście będę się opierała na tym ostatnim, odwołując się do badań z wykorzystaniem kwestionariusza opracowanego na jego podstawie, przybliżę go w nieco pełniejszym stopniu. Ivan Brown i współpracownicy określają jakość życia jako ,poziom zadowolenia osoby z ważnych możliwości, jakie daje jej życie" (Raphael i in., 1999, s. 158). Na ogólną jakość życia składają się trzy dziedziny: Bycie (Being), Przynależność (Belonging) i Stawanie się (Becoming), a w każdej z nich wyróżnione są subdziedziny. Pierwsza dziedzina koncentruje się na tym, kim osoba jest, i zawiera takie subdziedziny, jak: bycie fizyczne, bycie psychologiczne i bycie duchowe. Przynależność dotyczy dobrego przystosowania się do różnych warunków życia i można wyróżnić takie jej subdziedziny, jak: przynależność fizyczną, przynależność społeczną, przynależność wspólnotową. Dziedzina Stawanie się odnosi się do angażowania się w sensowną aktywność, która łączy się z osiąganiem celów, realizacją marzeń i nadziei, z rozwijaniem samego siebie. Składają się na nią następujące subdziedziny: stawanie się praktyczne, czas wolny i rozwój. Poszczególne kwestie tworzące subdziedziny oceniane są pod względem znaczenia dla osoby i zadowolenia z nich. Określa się też dostępne możliwości do polepszenia jakości życia w każdej z wyróżnionych dziedzin, a także poczucie kontroli nad nimi. Autorzy stwierdzają, iż jakość życia jest szczególnie duża, gdy osoba doświadcza zadowolenia z tych dziedzin życia, które są dla niej ważne.

\section{Jakość życia rodziny osoby z niepelnosprawnością intelektualną}

Pierwsze prace dotyczące jakości życia rodziny osób z niepełnosprawnością intelektualną pojawiły się w latach 90 . XX wieku. Jednym $\mathrm{z}$ powodów ich prowadzenia było uznanie za istotne podejścia skoncentrowanego na rodzinie (family-centered approach), zgodnie z którym profesjonalna pomoc powinna być zapewniona całej rodzinie, a nie tylko dziecku niepełnosprawnemu. W podejściu tym poznanie warunków życia rodziny jest ważne, aby móc ją wspierać i wyposażyć w zasoby służące sprostaniu wymogom, które są jej stawiane. Innym powodem rozwoju prac nad jakością życia rodziny było uznanie, iż dotychczas prowadzone badania nad wpływem niepełnosprawności dziecka na przeżycia rodziców i funkcjonowanie rodziny mają bardzo wąski i specyficzny charakter (Summers i in., 2005; Poston i in., 2003). Zaproponowany zaś konstrukt jest wielowymiarowy i wieloaspektowy. Ujmuje rodzinę w szerszej perspektywie, dotyczy wielu dziedzin jej życia, a także doświadczeń wszystkich jej członków. Uwzględnia on wiele aspektów funkcjonowania rodziny i jej członków, np.: warunki życia rodziny, pozytywne i negatywne doświadczenia członków rodziny, cechy i jakość relacji między członkami rodziny. Oceniane są one zarówno subiektywnie, jak i obiektywnie. Wydaje się, że omawiany konstrukt ułatwia zrozumienie doświadczeń wszystkich członków rodziny, potrzeby i motywy ich działania zarówno na indywidualnym poziomie, jak i na poziomie członka rodziny. Konstrukt ten ukazuje też wpływ osoby z niepełnosprawnością intelektualną na pozostałych członków rodziny (McIntyre i in., 2004) oraz na rodzinę jako całość i na strukturę rodziny (Isaacs i in., 2007; Brown i in., 2006; Skinner, Weisner, 2007). Można także określić wpływ funkcjonowania, cech i dobrostanu rodziców lub innych członków rodziny na osobę niepełnosprawną (za: Head, Abbeduto, 2007). Wyniki badań nad jakością życia rodzin osób niepełnosprawnych wydają się ważnymi danymi dla polityki społecznej (Bailey i in., 1998; Wang, Brown, 2009).

Podstawę teoretyczną konstruktu tworzą teorie systemowe, zgodnie z którymi członkowie rodziny, czyli elementy systemu, są wzajemnie od siebie zależni, a rodzina stanowi „złożoną, zintegrowaną całość, charakteryzującą się zorganizowanymi wzorami interakcji, 
które przybierają raczej cyrkularką niż linearną formę" (Minuchin, 1988, s. 8, cyt. za: Harwas-Napierała, 2009, s. 12). Obecnie najbardziej znane prace dotyczące omawianego konstruktu pochodzą z dwóch ośrodków. Pierwszy z nich to Beach Center on Disability przy Uniwersytecie w Kansas w USA. Drugi ośrodek, w którym prowadzone są prace dotyczące koncepcji oraz badania nad jakością życia rodzin osób z niepełnosprawnością intelektualną, to Centrum Promocji Zdrowia przy Uniwersytecie w Toronto. Głównym badaczem kierującym pracami tego ośrodka jest Ivan Brown. Pod kierunkiem Browna rozpoczął się w 1997 roku Międzynarodowy Projekt Jakości Życia Rodziny (International Family Quality of Life Project). Został on podjęty początkowo przez badaczy $z$ takich państw, jak: Australia, Kanada, Izrael. Badacze uzgodnili wiele kwestii dotyczących omawianego konstruktu. Mianowicie uzgodnili, że ma on naturę holistyczną, dotyczy bowiem wielu dziedzin i doświadczeń wszystkich członków rodziny oraz rodziny jako całości. Ma charakter wielowymiarowy. Ujmuje zarówno obiektywny, jak i subiektywny aspekt jakości życia rodziny. W modelu wyróżniono następujących dziewięć dziedzin jakości życia rodziny: Zdrowie rodziny (Health of the family), Sytuacja finansowa ( $F i$ nancial well-being), Relacje rodzinne (Family relationships), Wsparcie innych ludzi (Support from other people), Wsparcie ze strony usług specjalistycznych i pomocy społecznej (Support from disability-related services), System wartości (Influence of values), Kariera zawodowa i przygotowanie do niej (Careers and preparing for careers), Czas wolny i rekreacja (Leisure and recreation), Interakcje społeczne (Community interaction). Każda z tych dziedzin może być analizowana na sześciu następujących wymiarach: znaczenie, możliwości, inicjatywa, osiągnięcia, stabilność, satysfakcja. Te wymiary są jednocześnie wskaźnikami subiektywnej jakości życia rodzinnego w poszczególnych dziewięciu dziedzinach. Autorzy dodają ponadto, iż, podobnie jak indywidualną jakość życia, również jakość życia rodziny należy analizować w sposób obiektywny, określając warunki życia rodziny, oraz w sposób subiektywny, uwzględniając adaptację do tych warunków, ich ocenę oraz zadowolenie z nich członków rodziny. Sugerują również, iż ogólna ocena jakości życia rodziny oraz poziom zadowolenia $\mathrm{z}$ niego nie muszą być tożsame $\mathrm{z}$ ocenami poszczególnych dziedzin (Brown i in., 2003; Brown i in., 2006; Brown, Schalock, Brown, 2009). Na podstawie wyżej omówionego modelu powstała w 2000 roku pierwsza wersja narzędzia, a w 2006 roku - druga, nieco zmodyfikowana, nosząca nazwę: Family Quality of Life Survey - 2006.

\section{Jakość życia rodziny a jakość życia osób dorosłych z lekką niepełnosprawnością intelektualną - przegląd literatury przedmiotu}

Chociaż wielu autorów (Brown, Brown, 2005; Summers i in., 2005) podkreśla, iż jakość życia każdego członka rodziny jest unikatowa, związana z osobistymi ambicjami, potrzebami, życzeniami, zasobami i umiejętnościami, jakości życia rodziców i całej rodziny nie da się rozdzielić od jakości życia syna i córki, szczególnie gdy syn i córka żyją w domu rodzinnym. Wiele danych empirycznych wskazuje na współzależności między dobrostanem rodziców i ich funkcjonowaniem oraz jakością życia ich niepełnosprawnych dzieci. McIntyre i współpracownicy (2004) na podstawie wywiadów z matkami dorosłych dzieci z głębszą niepełnosprawnością intelektualną podkreślają, że na jakość życia całej rodziny i poszczególnych jej członków ma wpływ osoba z niepełnosprawnością intelektualną i jej jakość życia. Przegląd badań (Seltzer, Krauss, 1989; Zasępa, Węglewska, 2007) ukazuje też oddziaływanie rodziny, jej specyficznego klimatu, struktury, zasobów rodzinnych, planów na przyszłość, relacji małżeńskiej na funkcjonowanie dziecka $\mathrm{z}$ niepełnosprawnością intelektualną. Badania przeprowadzone przez Jane Murray Cramm i Annę Petrę Nieboer (2012) wskazują na to, iż istotnymi predyktorami jakości życia dzieci są: społeczny i emocjonalny dobrostan rodziców oraz korzystna zmiana w ciągu roku w zakresie społecznego i emocjonalnego dobrostanu rodziców.

W literaturze przedmiotu nie znaleziono badań, poza jednym opisanym poniżej, które 
dotyczyłyby poszukiwania zależności między jakością życia rodziny - konstruktu mającego wielowymiarowy i wieloaspektowy charakter - a jakością życia dziecka $\mathrm{z}$ niepełnosprawnością intelektualną. Dlatego wyniki tego badania nieco dokładniej zostaną opisane. Bertelli i współpracownicy (2011), badając we Włoszech jakość życia rodziny oraz subiektywną jakość życia dorosłych dzieci z niepełnosprawnością intelektualną w wieku 27-50 lat mieszkających w większości poza rodziną pochodzenia, uzyskali wyniki złożone i często trudne w interpretacji. Mianowicie między ogólnym poziomem jakości życia rodziny mierzonym przy zastosowaniu kwestionariusza FQOLS-2006 a ogólną jakością życia osób z niepełnosprawnością intelektualną mierzoną za pomocą Profilu Jakości Życia Browna nie stwierdzono istotnych zależności. Między trzema dziedzinami jakości życia dorosłych dzieci a dziewięcioma dziedzinami jakości życia rodziny określonymi w sposób subiektywny przy zastosowaniu sześciu wskaźników znaleziono dwadzieścia istotnych współczynników korelacji. Wśród nich czternaście ma znak ujemny, sześć zaś - dodatni. Wyniki te autorzy próbują zinterpretować następująco. Ujemny związek między satysfakcją, jaką osoby mają z dziedziny Bycie, a możliwościami w zakresie Sytuacji finansowej rodziny może wskazywać na to, iż niższa satysfakcja w dziedzinie Bycia dorosłych dzieci z niepełnosprawnością intelektualną żyjących w rodzinach lepiej sytuowanych może być spowodowana odczuciem większego kontrastu między ich sytuacją materialną a sytuacją innych członków rodziny. Ujemne zależności między możliwościami rodziny uzyskania Wsparcia od innych a jakością życia dorosłego dziecka w dziedzinie Bycie i Stawanie się mogą świadczyć o jego dużej potrzebie autonomii. Ujemne zależności między możliwościami w Sytuacji finansowej rodziny a jakością życia dzieci w dziedzinie Przynależność mogą wskazywać na większe tendencje do tworzenia bliskich relacji w rodzinach żyjących w trudniejszych warunkach socjoekonomicznych. Ujemne zależności między jakością życia dorosłych dzieci z niepełnosprawnością intelektualną w dziedzinie Stawanie się a Sytuacją finansową i Relacjami w rodzinie mogą wynikać z silniejszych aspiracji, potrzeb i nadziei dzieci, w których rodzinach jest trudniejsza sytuacja finansowa i rodzinna. Dodatnie zależności między znaczeniem, jakie rodzina przypisuje usługom specjalistycznym, a jakością życia dorosłych dzieci mogą wskazywać na docenienie starań rodziny, także na rzecz poprawy ich funkcjonowania (Bertelli i in., 2011).

\section{METODA}

\section{Problem badawczy}

Celem badań jest określenie zależności między jakością życia rodziny osób u progu dorosłości z lekką niepełnosprawnością intelektualną a subiektywnie ocenioną jakością ich życia. Dokładniej cel ten można przedstawić w następujących pytaniach badawczych:

1. Jaka jest jakość życia młodych dorosłych z lekką niepełnosprawnością intelektualną?

2. Jaka jest jakość życia rodziny dzieci z lekką niepełnosprawnością intelektualną wchodzących w dorosłość?

3. Czy istnieje zależność między jakością życia rodziny a jakością życia dzieci z lekką niepełnosprawnością intelektualną wkraczających w dorosłość?

Do pytań tych nie sformułowano hipotez badawczych. Mają one charakter eksploracyjny. Przyjęto, iż uzyskanie odpowiedzi na nie przyczyni się do głębszego poznania doświadczeń rodziny oraz życia młodych dorosłych z lekką niepełnosprawnością intelektualną.

\section{Techniki badawcze}

Do określenia jakości życia rodziny osób $\mathrm{z}$ niepełnosprawnością intelektualną posłużył Kwestionariusz Jakości Życia Rodziny (Family Quality of Life Survey - general version, FQoLS-2006), autorstwa Ivana Browna i współpracowników (2011), w polskim tłumaczeniu Ewy Zasępy, Ewy Wapiennik i Agnieszki Wołowicz (Zasępa, Wołowicz, 2010). Kwestionariusz ten mierzy 9 dziedzin jakości życia rodziny: Zdrowie rodziny (Health of the family), Sytuację finansową (Financial well- 
-being), Relacje rodzinne (Family relationships), Wsparcie innych osób (Support from other people), Pomoc społeczną i usługi specjalistyczne (Support from disability-related services), System wartości (Spiritual and cultural beliefs), Karierę zawodową i przygotowanie do kariery (Careers and preparing for careers), Czas wolny i rekreację (Leisure and enjoyment of life), Interakcje społeczne (Community and civic involvement). Na początku kwestionariusza zawarte są pytania o dane dotyczące rodziny oraz osoby niepełnosprawnej. Ostatnia zaś część dotyczy ogólnej oceny jakości życia rodziny. Każda z 9 dziedzin jakości życia rodziny określana jest w sposób obiektywny (część A) oraz w sposób subiektywny (część B). W obu częściach zawarte są pytania zamknięte (dane ilościowe) oraz otwarte (dane jakościowe). W części A co najmniej jeden członek rodziny opisuje możliwie najpełniej i najdokładniej obiektywne warunki życia rodziny i doświadczenia jej członków. Na przykład, oceniając obiektywnie pierwszą z dziedzin, czyli Zdrowie rodziny, należy określić, kto z członków rodziny ma problemy ze zdrowiem somatycznym lub psychicznym i jakiego one są rodzaju. Wskazuje też, czy członkowie rodziny mają trudności w korzystaniu $z$ usług medycznych i jakiego rodzaju. Informacje uzyskane z części A służą według autorów głębszemu poznaniu funkcjonowania rodziny oraz próbie interpretacji wyników w drugiej części. W części B znajdują się bowiem itemy charakteryzujące każdą z dziewięciu dziedzin jakości życia rodziny na sześciu wymiarach: znaczenie, możliwości, inicjatywa, osiągnięcia, stabilność i satysfakcja. Osoba wypełniająca kwestionariusz ustosunkowuje się do nich na 5-stopniowej skali Likerta. Wymiary te podzielone są na dwie grupy. Pierwszą z nich tworzą osiągnięcia i satysfakcja, które zostały określone jako wskaźniki wyników, zaś drugą grupę tworzą cztery pozostałe, które zostały nazwane wskaźnikami eksploracyjnymi. Autorzy sugerują, iż w analizach można wykorzystywać tylko wskaźniki wyników. Skala możliwych do uzyskania rezultatów, zarówno w zakresie wskaźników wyników, jak i wskaźników eksploracyjnych, to 1-5 punktów. Kwestio- nariusz Jakości Życia Rodziny może być wypełniany przez rodzica, rodzeństwo, małżonka lub jeszcze inną osobę z najbliższej rodziny. Może być uzupełniany w trakcie wywiadu lub samodzielnie przez respondenta. Wypełnienie kwestionariusza zajmuje około jednej godziny. Oszacowania właściwości psychometrycznych kwestionariusza wskazują na to, iż zarówno wersja oryginalna (Brown i in., 2003; Brown $\mathrm{i}$ in., 2006; Isaacs $\mathrm{i}$ in., 2007), jak i jej polskie tłumaczenie (Zasępa, Wołowicz, 2010) rzetelnie i trafnie mierzą jakość życia rodziny osób z niepełnosprawnością intelektualną. Współczynniki rzetelności (alfa Cronbacha) obliczonej metodą zgodności wewnętrznej są dla polskiego tłumaczenia dla większości dziedzin jakości życia rodziny powyżej wartości .70 (wahają się od .72 - dla Wsparcia w ramach specjalistycznych usług i pomocy społecznej do .85 - dla Czasu wolnego i rekreacji). Niższe współczynniki uzyskano dla dwóch dziedzin, tj. dla: Zdrowia rodziny (.44) i dla Sytuacji finansowej (.68). Do oceny jakości życia rodziny w tych dwu dziedzinach należy podchodzić z większą ostrożnością. Mniejsza zgodność wewnętrzna w nich może wynikać z większego niż w pozostałych dziedzinach zróżnicowania $\mathrm{w}$ ocenie na poszczególnych sześciu wymiarach, np. zazwyczaj znaczenie zdrowia członków rodziny czy sytuacji finansowej rodziny jest bardzo duże dla ogólnej jakości życia rodziny, a osiągnięcia i satysfakcja z nich są mniejsze. Na trafność diagnostyczną narzędzia wskazują istotne współczynniki korelacji między wynikami uzyskanymi w nim a ogólnym rezultatem uzyskanym w Skali Satysfakcji Cząstkowych Czapińskiego wypełnianej przez członków rodziny.

Aby określić jakość życia osób dorosłych $\mathrm{z}$ lekką niepełnosprawnością intelektualną, zastosowano kwestionariusz Profil Jakości Życia (Quality of Life Profile) Browna i współpracowników (por. Raphael i in., 1999) w polskim tłumaczeniu Zasępy, Wapiennik i Wołowicz. Kwestionariusz ten mierzy subiektywną jakość życia osób w trzech dziedzinach: Bycie $(B e-$ ing), Przynależność (Belonging) i Stawanie się (Becoming). Każda $\mathrm{z}$ tych dziedzin ma swoje subdziedziny, które zostały opisane we wpro- 
wadzeniu do tego artykułu. Kwestionariusz zawiera 54 pozycje, które są oceniane dwukrotnie: w pierwszym etapie pod względem znaczenia danej sprawy, a w drugim - pod względem satysfakcji z niej. Określają one również dostępne możliwości do polepszenia jakości życia w każdej z wyróżnionych dziedzin, a także poczucie kontroli nad nimi (części kwestionariusza mierzących kontrolę i możliwości nie analizowano w tych badaniach). Autorzy proponują, aby uzyskane wyniki interpretować w sposób następujący: poniżej -4,5 - bardzo problematyczna (very problematic) jakość życia, od $-4,5$ do $-1,5$ - problematyczna (problematic), od $-1,5$ do 1,5 - umiarkowana (adequate situation), od 1,5 do 4,5 - wysoka (very acceptable) i powyżej 4,5 - bardzo wysoka (excellent) jakość życia. Badanie prowadzone jest indywidualnie, a do poszczególnych pozycji osoba ustosunkowuje się w trakcie prowadzonej rozmowy o wymienionych sprawach życiowych. Przykładowo w kontekście tego, jak ważny jest w życiu osoby sposób odżywiania się, pytano: „Co lubisz jeść?". Badanie trwa około 1 godziny, zazwyczaj podzielone jest na dwa etapy. Kwestionariusz Profil Jakości Życia spełnia wymogi psychometryczne i przy jego zastosowaniu można rzetelnie i trafnie określić jakość życia osób z lekką niepełnosprawnością intelektualną (Zasępa, 2011). Współczynniki rzetelności alfa Cronbacha polskiego thumaczenia są wysokie i wynoszą: dla wyniku ogólnego .97, dla dziedziny Bycie .92, dla dziedziny Przynależność .93 i dla dziedziny Stawanie się .87. Trafność diagnostyczną narzędzia oszacowano przez korelację uzyskanych w nim wyników z wynikiem ogólnym w Skali Jakości Życia Sławomiry Sadowskiej. Otrzymano istotne dodatnie współczynniki korelacji, a mianowicie dla ogólnej jakości życia $.66(p=.001)$, dla dziedziny Bycie $.63(p=.001)$, dla dziedziny Przynależność .66 $(p=.001)$ i dla dziedziny Stawanie się $.57(p=.001)$.

\section{Osoby badane}

W badaniu wzięło udział 27 młodych dorosłych z lekką niepełnosprawnością intelektualną. Wśród nich było 14 mężczyzn i 13 kobiet.
Ich wiek życia mieścił się w przedziale 18-23 lata $(M=18,89 ; S D=1,25)$. Byli to uczniowie zawodowych szkół specjalnych mieszkający w domach rodzinnych. 7 spośród nich mieszkało w średniej wielkości mieście, 3 - w małym mieście i 17 - na wsi. W rodzinach pełnych żyło 15 osób $(55,6 \%)$, w rodzinach niepełnych, w których głównym opiekunem była matka, żyło 10 osób (37\%), a w zrekonstruowanych - 2 osoby (7,4\%). Osobą oceniającą jakość życia rodziny była matka $(N=27)$. Wiek mam mieścił się w przedziale $39-57$ lat $(M=47,48 ; S D=4,71)$. Podany wiek ojców był w przedziale 41-60 lat $(M=50,79 ; S D=5,33)$.

\section{Przebieg badania}

Badania miały charakter dobrowolny, a ankietowani zostali poinformowani o poufności. Prowadzone były w sposób indywidualny na terenie szkoły. Kwestionariusz Jakości Życia Rodziny wypełniały matki. Po umówieniu na zebraniu klasowym lub indywidualnie matki spotykały się z autorką badania lub psychologiem szkolnym. W jego trakcie przedstawiano cel badania oraz sposób udzielania odpowiedzi. Niektóre mamy chciały samodzielnie wypełnić kwestionariusz w domu. Z pozostałymi uzupekniano go w trakcie wywiadu. Młodych dorosłych badano indywidualnie na terenie szkoły. Zawsze uzupełniali oni kwestionariusz podczas prowadzonej z nimi rozmowy.

Do badań włączono osoby mieszkające zarówno w rodzinach pełnych, jak i niepełnych. Przyjęto za autorami Kwestionariusza Jakości Życia Rodziny (Brown i in., 2006, s. 239), że ,rodzina to osoby, których ściśle dotyczą wspólne codzienne domowe sprawy rodziny. Członkowie rodziny mogą być ze sobą spokrewnieni lub związani ze sobą poprzez bliskie osobiste relacje".

\section{WYNIKI}

Analiza wyników zostanie rozpoczęta od charakterystyki jakości życia młodych dorosłych $\mathrm{z}$ niepełnosprawnością intelektualną (tabela 1) oraz jakości życia ich rodzin (tabela 2). 
Tabela 1. Średnie wyniki uzyskane w poszczególnych dziedzinach i subdziedzinach jakości życia przez młodych dorosłych z lekką niepełnosprawnością intelektualną

\begin{tabular}{|l|c|c|}
\hline \multicolumn{1}{|c|}{ Subdziedzina/dziedzina jakości życia } & $\boldsymbol{M}$ & $\boldsymbol{S D}$ \\
\hline Bycie fizyczne & 3.54 & 2.65 \\
\hline Bycie psychologiczne & 2.66 & 2.76 \\
\hline Bycie duchowe & 3.52 & 2.40 \\
\hline Bycie & 3.23 & 2.33 \\
\hline Przynależność fizyczna & 3.65 & 3.19 \\
\hline Przynależność społeczna & 3.35 & 2.62 \\
\hline Przynależność wspólnotowa & 2.13 & 3.00 \\
\hline Przynależność & 3.01 & 2.56 \\
\hline Stawanie się praktyczne & 3.78 & 2.75 \\
\hline Czas wolny & 3.05 & 2.49 \\
\hline Rozwój osobisty & 3.18 & 2.58 \\
\hline Stawanie się & 3.28 & 2.37 \\
\hline Jakość życia - ogółem & 3.14 & 2.27 \\
\hline
\end{tabular}

Źródło: opracowanie własne.

Tabela 2. Średnie wyniki uzyskane w subiektywnie ocenionych dziedzinach jakości życia rodziny osób z lekką niepełnosprawnością intelektualną

\begin{tabular}{|l|c|c|}
\hline \multicolumn{1}{|c|}{ Dziedziny jakości życia rodziny } & $\boldsymbol{M}$ & .78 \\
\hline Zdrowie rodziny & 3.20 & .95 \\
\hline Sytuacja finansowa & 2.48 & .96 \\
\hline Relacje rodzinne & 3.50 & .83 \\
\hline Wsparcie innych osób & 2.24 & .65 \\
\hline Pomoc społeczna i usługi specjalistyczne & 2.37 & .82 \\
\hline System wartości & 3.03 & .86 \\
\hline Kariera zawodowa i przygotowanie do kariery & 2.70 & .88 \\
\hline Czas wolny i rekreacja & 2.83 & .83 \\
\hline Interakcje społeczne & 2.75 & .84 \\
\hline Jakość życia rodziny - ogólna ocena & 2.41 & .97 \\
\hline Jakość życia rodziny - ogólna satysfakcja & 2.89 & \\
\hline
\end{tabular}

W tabeli przedstawiono uśrednione wyniki uzyskane w zakresie dwóch wymiarów: osiągnięć i satysfakcji. Są one wskaźnikami wyników.

Źródło: opracowanie własne. 
Średnie rezultaty uzyskane w zakresie jakości życia badanych osób mieszczą się w przedziale wyników wysokich zarówno w zakresie wyniku ogólnego, jak i w poszczególnych dziedzinach i subdziedzinach. Choć warto zauważyć, iż odchylenia standardowe są stosunkowo duże, co wskazuje na zróżnicowanie ocen. Najniższy wynik stwierdzono w zakresie Przynależności wspólnotowej, najwyższy zaś - w zakresie Stawania się praktycznego.

Uzyskane dane wskazują na zróżnicowany obraz doświadczeń rodzinnych. Ogólna ocena i ogólna satysfakcja są nieco poniżej średniej, co świadczy o niezbyt wysokiej jakości życia badanych rodzin oraz licznych potrzebach, które nie są zaspokojone. Najwyższe wskaźniki jakości życia rodziny (znajdujące się nieco powyżej średniego punktu wynoszącego 3 pkt) występują w zakresie Relacji rodzinnych, Zdrowia rodziny i Systemu wartości, najmniejsze zaś dotyczą: Wsparcia innych osób, Pomocy społecznej i usług specjalistycznych oraz Sytuacji finansowej.

Analiza części obiektywnej A wskazuje na to, iż w rodzinach w większości obowiązki dzielone są między poszczególnych członków, którzy pomagają sobie wzajemnie, wspierają się w trudnych chwilach, ufają sobie, są ze sobą związani. Choć też można zauważyć pewną ich autonomię. Rzadko wybierają się wspólnie w różne miejsca czy bawią się razem w swoim towarzystwie. W sferze zdrowia rodziny oceniają się raczej dobrze. Opisując stan zdrowia swoich członków z niepełnosprawnością intelektualną, w 3 przypadkach podano, iż występują u nich problemy zdrowotne (gastrologiczne, wodogłowie, psychiatryczne). U 8 członków rodziny stwierdzono różnej natury problemy zdrowotne: endokrynologiczne, onkologiczne, psychiatryczne. Rodziny raczej dobrze radzą sobie z tymi problemami. Choć też wskazują na pewne trudności w dostępie do usług zdrowotnych, takich jak najczęściej: brak danej usługi w okolicy, trudności w dojeździe, długi czas czekania na usługę, nieznany sposób leczenia danego schorzenia. Dla rodzin ważny jest system wartości, zwłaszcza religijnych, oraz kierowanie się osobistymi standardami, takimi jak ,dobroć, miłość”, „uczciwość, pracowitość”. Z kolei wsparcie innych osób, zarówno praktyczne, jak i emocjonalne, zostało ocenione nisko. 23 rodziny na przykład podają, iż od krewnych w ogóle nie otrzymują wsparcia praktycznego lub jest ono bardzo małe, zaś w 21 przypadkach - nie mają wsparcia emocjonalnego. Tylko 2 rodziny wskazują na wsparcie praktyczne ze strony sąsiadów i przyjaciół, a 4 na wsparcie emocjonalne. Pomoc udzielana rodzinie przez odpowiednie instytucje też została oceniona stosunkowo nisko. Wiele z nich pisze o potrzebie zasiłków i pomocy finansowej. W 7 rodzinach tylko kilka, a w 10 część podstawowych potrzeb jest zaspokojonych. W blisko połowie rodzin mama lub oboje rodzice są rencistami, emerytami lub bezrobotnymi. Wiąże się to $\mathrm{z}$ trudną sytuacją finansową rodzin. 10 spośród nich oceniło swoją sytuację finansową na tle całego kraju jako znacznie poniżej średniej, 9 - jako poniżej średniej i 8 -jako przeciętną.

Analizy uzyskanych wyników badań koncentrują się na poszukiwaniu zależności między obiektywną i subiektywną jakością życia rodziny a subiektywnie ocenioną jakością życia wchodzących w dorosłość dzieci z lekką niepełnosprawnością intelektualną. Zależności te oszacowano ze względu na małą grupę badawczą przy zastosowaniu współczynnika rho-Spearmana (tabela 3 i 4). 
Tabela 3. Współczynniki korelacji między obiektywną jakością życia rodziny a jakością życia dorosłych dzieci z niepełnosprawnością intelektualną

\begin{tabular}{|c|c|c|c|c|}
\hline & Bycie & Przynależność & Stawanie się & $\begin{array}{l}\text { Jakość życia - } \\
\text { wynik ogólny }\end{array}$ \\
\hline Zdrowie rodziny & $\begin{array}{l}\text { Problemy } \\
\text { zdrowotne } \\
\text { członków rodziny: } \\
-.14\end{array}$ & $\begin{array}{l}\text { Problemy } \\
\text { zdrowotne } \\
\text { członków rodziny: } \\
.06\end{array}$ & $\begin{array}{l}\text { Problemy } \\
\text { zdrowotne } \\
\text { członków rodziny: } \\
-.03\end{array}$ & $\begin{array}{l}\text { Problemy } \\
\text { zdrowotne } \\
\text { członków rodziny: } \\
-.09\end{array}$ \\
\hline $\begin{array}{l}\text { Sytuacja } \\
\text { finansowa }\end{array}$ & Dochód/os: .36 & Dochód/os: .62*** & Dochód/os: $.56^{* *}$ & Dochód/os: .46** \\
\hline Relacje rodzinne & Relacje: -.30 & Relacje: $-.44 *$ & Relacje: $-.53^{* *}$ & Relacje: $-.46^{*}$ \\
\hline $\begin{array}{l}\text { Wsparcie innych } \\
\text { osób }\end{array}$ & $\begin{array}{l}\text { Krewni/ } \\
\text { praktyczne: } .26 \\
\text { Krewni// } \\
\text { emocjonalne: } .27\end{array}$ & $\begin{array}{l}\text { Krewni/pr.: } .37 \\
\text { Krewni/em.: .45** }\end{array}$ & $\begin{array}{l}\text { Krewni/pr.: .38* } \\
\text { Krewni/em.: .38* }\end{array}$ & $\begin{array}{l}\text { Krewni/pr.: .40* } \\
\text { Krewni/em.: .41* }\end{array}$ \\
\hline $\begin{array}{l}\text { Pomoc } \\
\text { społeczna } \\
\text { i usługi } \\
\text { specjalistyczne }^{1}\end{array}$ & - & - & - & - \\
\hline System wartości & $\begin{array}{l}\text { Akceptacja }^{2}: .06 \\
\text { Pomoc } \\
\text { praktyczna }:-.15 \\
\text { Pomoc } \\
\text { emocjonalna }{ }^{4}:-.12\end{array}$ & $\begin{array}{l}\text { Akceptacja }^{2}: .04 \\
\text { Pomoc } \\
\text { praktyczna }:-.09 \\
\text { Pomoc } \\
\text { emocjonalna }{ }^{4}:-.10\end{array}$ & $\begin{array}{l}\text { Akceptacja }^{2}: .02 \\
\text { Pomoc } \\
\text { praktyczna }^{3}:-.08 \\
\text { Pomoc } \\
\text { emocjonalna }{ }^{4}:-.05\end{array}$ & $\begin{array}{l}\text { Akceptacja }^{2}: .04 \\
\text { Pomoc } \\
\text { praktyczna }^{3}:-.12 \\
\text { Pomoc } \\
\text { emocjonalna }{ }^{4}:-.10\end{array}$ \\
\hline $\begin{array}{l}\text { Kariera } \\
\text { i przygotowanie } \\
\text { do kariery }\end{array}$ & $\begin{array}{l}\text { Przerwanie pracy: } \\
-.18\end{array}$ & $\begin{array}{l}\text { Przerwanie pracy: } \\
-.33\end{array}$ & $\begin{array}{l}\text { Przerwanie pracy: } \\
-.36\end{array}$ & $\begin{array}{l}\text { Przerwanie pracy: } \\
-.33\end{array}$ \\
\hline $\begin{array}{l}\text { Czas wolny } \\
\text { i rekreacja }{ }^{5}\end{array}$ & - & - & - & - \\
\hline $\begin{array}{l}\text { Interakcje } \\
\text { społeczne }\end{array}$ & $\begin{array}{l}\text { Dyskryminowanie } \\
\text { członków rodziny: } \\
-.08 \\
\text { Rodzina lubi } \\
\text { społeczność: -.19 }\end{array}$ & $\begin{array}{l}\text { Dyskryminowanie } \\
\text { członków rodziny: } \\
-.02 \\
\text { Rodzina lubi } \\
\text { społeczność: -.16 }\end{array}$ & $\begin{array}{l}\text { Dyskryminowanie } \\
\text { członków rodziny: } \\
-.11 \\
\text { Rodzina lubi } \\
\text { społeczność: }-.01\end{array}$ & $\begin{array}{l}\text { Dyskryminowanie } \\
\text { członków rodziny: } \\
-.13 \\
\text { Rodzina lubi } \\
\text { społeczność: }-.05\end{array}$ \\
\hline
\end{tabular}

Legenda: $w$ zakresie relacji rodzinnych niższe wartości oznaczają lepszą jakość życia; * $-p<.05, * *-p<.01$, $* * *-p<.001 ;{ }^{1}-\mathrm{w}$ dziedzinie Pomoc społeczna i usługi specjalistyczne osoby wymieniają rodzaj usług specjalistycznych, z których korzystają, oraz rodzaj barier w dostępie do tych usług; ${ }^{2}-\mathrm{w}$ dziedzinie System wartości osoba określa, w jakim stopniu osoby ze wspólnot religijnych, duchowych, kulturowych, do których przynależy rodzina, akceptująjej członków; ${ }^{3}$-wdziedzinieSystem wartościosobaokreśla, wjakimstopniu osobyzewspólnotreligijnych, duchowych, kulturowych, do których przynależy rodzina, pomagają jej praktycznie; ${ }^{4}$ - w dziedzinie System wartości osoba określa, w jakim stopniu osoby ze wspólnot religijnych, duchowych, kulturowych, do których przynależy rodzina, wspierają ją emocjonalnie; ${ }^{5}$ - w dziedzinie czas wolny osoby wymieniają formy spędzania czasu wolnego.

Źródło: opracowanie własne. 
Tabela 4. Współczynniki korelacji między subiektywną jakością życia rodziny a jakością życia dorosłych dzieci z niepełnosprawnością intelektualną $(N=27)$

\begin{tabular}{|c|c|c|c|c|}
\hline & Bycie & Przynależność & Stawanie się & $\begin{array}{l}\text { Jakość życia - } \\
\text { wynik ogólny }\end{array}$ \\
\hline Zdrowie rodziny & $\begin{array}{r}\text { Z: } .17 \\
\text { M: } .08 \\
\text { I: } .32 \\
\text { O: }-.03 \\
\text { St: } .21 \\
\text { S: } .26 \\
\end{array}$ & $\begin{array}{c}\text { Z: } .32 \\
\text { M: } .16 \\
\text { I: } .30 \\
\text { O: } .39 * \\
\text { St: } .30 \\
\text { S: } .48^{* *}\end{array}$ & $\begin{array}{c}\text { Z: } .23 \\
\text { M: } .31 \\
\text { I: .29 } \\
\text { O: } .26 \\
\text { St: } .30 \\
\text { S: } .40^{*} \\
\end{array}$ & $\begin{array}{c}\text { Z: } .18 \\
\text { M: } .12 \\
\text { I: .23 } \\
\text { O: } .16 \\
\text { St: } .29 \\
\text { S: } .39 * \\
\end{array}$ \\
\hline Sytuacja finansowa & $\begin{array}{c}\text { Z: }-.23 \\
\text { M: } .20 \\
\text { I: } .12 \\
\text { O: } .25 \\
\text { St: } .09 \\
\text { S: } .46^{* *}\end{array}$ & $\begin{array}{l}\text { Z: } .01 \\
\text { M: } .42^{*} \\
\text { I: } .24 \\
\text { O: } .50^{* *} \\
\text { St: } .24 \\
\text { S: } .51^{* *}\end{array}$ & $\begin{array}{l}\text { Z: }-.10 \\
\text { M: } .52^{* *} \\
\text { I: } .20 \\
\text { O: } .51^{* *} \\
\text { St: } .33 \\
\text { S: } .60^{* * *}\end{array}$ & $\begin{array}{c}\text { Z: }-.17 \\
\text { M: } .32 \\
\text { I: } .14 \\
\text { O: } .39^{*} \\
\text { St: } .22 \\
\text { S: } .50^{* *}\end{array}$ \\
\hline Relacje rodzinne & $\begin{array}{r}\text { Z: } .31 \\
\text { M: } .16 \\
\text { I: } .15 \\
\text { O: } .21 \\
\text { St: }-.08 \\
\text { S: } .26\end{array}$ & $\begin{array}{c}\text { Z: } .52^{* *} \\
\text { M: } .31 \\
\text { I: } .35 \\
\text { O: } .34 \\
\text { St: } .02 \\
\text { S: } .35\end{array}$ & $\begin{array}{c}\text { Z: } .57^{* *} \\
\text { M: } .31 \\
\text { I: } .39^{*} \\
\text { O: } .43^{*} \\
\text { St: } .12 \\
\text { S: } .40^{*}\end{array}$ & $\begin{array}{r}\text { Z: } .43^{*} \\
\text { M: } .24 \\
\text { I: } .24 \\
\text { O: } .29 \\
\text { St: } .05 \\
\text { S: } .33\end{array}$ \\
\hline Wsparcie innych osób & $\begin{array}{r}\text { Z: }-.12 \\
\text { M: } .16 \\
\text { I: } .12 \\
\text { O: } .12 \\
\text { St: }-.08 \\
\text { S: } .08\end{array}$ & $\begin{array}{c}\text { Z: } .03 \\
\text { M: } .30 \\
\text { I: } .37^{*} \\
\text { O: } .33 \\
\text { St: } .14 \\
\text { S: } .30\end{array}$ & $\begin{array}{r}\text { Z: }-.06 \\
\text { M: } .30 \\
\text { I: } .22 \\
\text { O: } .29 \\
\text { St: } .15 \\
\text { S: } .23\end{array}$ & $\begin{array}{r}\text { Z: }-.07 \\
\text { M: } .34 \\
\text { I: } .26 \\
\text { O: } .32 \\
\text { St: } .08 \\
\text { S: } .26\end{array}$ \\
\hline $\begin{array}{l}\text { Pomoc społeczna } \\
\text { i usługi specjalistyczne }\end{array}$ & $\begin{array}{r}\text { Z: } .06 \\
\text { M: }-.26 \\
\text { I: } .20 \\
\text { O: } .01 \\
\text { St: }-.28 \\
\text { S: } .12\end{array}$ & $\begin{array}{r}\text { Z: } .12 \\
\text { M: }-.13 \\
\text { I: } .26 \\
\text { O: } .19 \\
\text { St: } .17 \\
\text { S: } .19\end{array}$ & $\begin{array}{r}\text { Z: }-.14 \\
\text { M: }-.08 \\
\text { I: } .17 \\
\text { O: } .08 \\
\text { St: } .19 \\
\text { S: } .25\end{array}$ & $\begin{array}{r}\text { Z: } .07 \\
\text { M: }-.16 \\
\text { I: } .26 \\
\text { O: } .09 \\
\text { St: }-.05 \\
\text { S: } .16\end{array}$ \\
\hline System wartości & $\begin{array}{r}\text { Z: }-.03 \\
\text { M: } .04 \\
\text { I: }-.23 \\
\text { O: }-.07 \\
\text { St: }-.19 \\
\text { S: } .08\end{array}$ & $\begin{array}{r}\text { Z: } .09 \\
\text { M: } .25 \\
\text { I: } .08 \\
\text { O: } .15 \\
\text { St: }-.10 \\
\text { S: } .26 \\
\end{array}$ & $\begin{array}{c}\text { Z: } .18 \\
\text { M: } .27 \\
\text { I: } .11 \\
\text { O: } .25 \\
\text { St: } .04 \\
\text { S: } .37^{*}\end{array}$ & $\begin{array}{r}\text { Z: } .02 \\
\text { M: } .17 \\
\text { I: }-.07 \\
\text { O: } .05 \\
\text { St: }-.06 \\
\text { S: } .18\end{array}$ \\
\hline $\begin{array}{l}\text { Kariera } \\
\text { i przygotowanie do } \\
\text { kariery }\end{array}$ & $\begin{array}{r}\text { Z: } .15 \\
\text { M: } .07 \\
\text { I: } .18 \\
\text { O: } .20 \\
\text { St: }-.04 \\
\text { S: }-.07\end{array}$ & $\begin{array}{c}\text { Z: } .28 \\
\text { M: } .27 \\
\text { I: } .38^{*} \\
\text { O: } .21 \\
\text { St: }-.09 \\
\text { S: } .16\end{array}$ & $\begin{array}{c}\text { Z: } .16 \\
\text { M: } .37 * \\
\text { I: } .26 \\
\text { O: } .44 * \\
\text { St: }-.07 \\
\text { S: } .23\end{array}$ & $\begin{array}{r}\text { Z: } .13 \\
\text { M: } .23 \\
\text { I: } .24 \\
\text { O: } .30 \\
\text { St: }-.05 \\
\text { S: } .06\end{array}$ \\
\hline Czas wolny i rekreacja & $\begin{array}{r}\text { Z: }-.10 \\
\text { M: } .08 \\
\text { I: }-.02 \\
\text { O: } .09 \\
\text { St: }-.10 \\
\text { S: } .07\end{array}$ & $\begin{array}{r}\text { Z: } .13 \\
\text { M: } .22 \\
\text { I: } .14 \\
\text { O: } .36 \\
\text { St: } .15 \\
\text { S: } .31\end{array}$ & $\begin{array}{c}\text { Z: } .07 \\
\text { M: } .36 \\
\text { I: } .19 \\
\text { O: } .38^{*} \\
\text { St: } .09 \\
\text { S: } .26\end{array}$ & $\begin{array}{r}\text { Z: }-.08 \\
\text { M: } .18 \\
\text { I: } .05 \\
\text { O: } .21 \\
\text { St: } .03 \\
\text { S: .15 }\end{array}$ \\
\hline
\end{tabular}




\begin{tabular}{|l|c|c|c|c|}
\hline & Bycie & Przynależność & Stawanie się & $\begin{array}{c}\text { Jakość życia - } \\
\text { wynik ogólny }\end{array}$ \\
\hline Interakcje społeczne & Z: .03 & Z: .23 & Z: .15 & Z: .07 \\
& M: .08 & M: .32 & M: .32 & M: .15 \\
& I: .05 & I: .28 & I: .23 & I: .14 \\
& O: .05 & O: .31 & O: .26 & O: .16 \\
& St: .05 & St: .24 & St: .29 & St: .24 \\
& S: .11 & S: .34 & S: .29 & S: .19 \\
\hline
\end{tabular}

Obliczono zależności między ogólną jakością życia młodych dorosłych z lekką niepełnosprawnością intelektualną a sześcioma wymiarami, tj.: Z - znaczenie, $\mathrm{M}$ - możliwości, I - inicjatywa, $\mathrm{O}$ - osiągnięcia, $\mathrm{St}$ - stabilność i S - satysfakcja, charakteryzującymi poszczególne dziedziny jakości życia rodziny; ${ }^{*}-p<.05,{ }^{* *}-p<.01$, $* * *-p<.001$.

Źródło: opracowanie własne.

Przeprowadzone badania ujawniły, iż obiektywna jakość życia rodziny określona w takich dziedzinach, jak: Sytuacja finansowa, Relacje rodzinne, Wsparcie innych osób, wiąże się istotnie z ogólną jakością życia dorosłych dzieci z niepełnosprawnością intelektualną oraz z jakością życia w dziedzinie Przynależność i Stawanie się. Zależności te mają charakter dodatni, umiarkowany. Wyniki te wskazują na to, że większy dochód przypadający na członka rodziny, lepsze relacje rodzinne, a także większy poziom wsparcia praktycznego (oprócz jakości życia w dziedzinie Przynależność) i emocjonalnego uzyskiwanego przez rodzinę od krewnych współwystępuje z większym ogólnym poziomem jakości życia młodych dorosłych z niepełnosprawnością intelektualną, a zwłaszcza z lepszą jakością życia w dziedzinach Przynależność i Stawanie się. Nie odnotowano istotnych zależności między jakością życia rodziny a jakością życia młodych dorosłych z niepełnosprawnością intelektualną w dziedzinie Bycie.

Wyniki badań dotyczące zależności między subiektywną jakością życia rodziny a subiektywną jakością życia wchodzących w dorosłość dzieci z niepełnosprawnością intelektualną ujawniły następujące prawidłowości. Wyższa jakość życia rodziny w dziedzinie Zdrowie rodziny, Sytuacja finansowa, Relacje rodzinne współwystępuje z wyższą ogólną jakością życia młodych dorosłych. Uzyskane współczynniki korelacji są dodatnie, wahają się od niskich do umiarkowanych. Wskazują one na to, iż jakość życia dorosłych dzieci jest wyższa wtedy, gdy rodzina odczuwa większą satysfakcję ze stanu zdrowia swoich członków, ponadto wyróżnia się większą satysfakcją i większe osiągnięcia w dziedzinie finansów. Młodzi dorośli z niepełnosprawnością intelektualną są bardziej zadowoleni z życia, gdy rodzina przywiązuje większą wagę do relacji rodzinnych. Satysfakcja rodziny ze swojej sytuacji finansowej jest istotnie dodatnio związana $\mathrm{z}$ zadowoleniem dorosłych dzieci z niepełnosprawnością intelektualną w dziedzinie Bycie.

Wyniki badań wskazują na to, iż większe osiągnięcia oraz satysfakcja rodziny ze stanu zdrowia swoich członków współwystępują z wyższą jakością życia dorosłych dzieci w dziedzinie Przynależność. Zadowolenie młodych dorosłych z otaczających warunków życia współwystępuje z większymi postrzeganymi przez członków rodziny możliwościami poprawy sytuacji finansowej, a także z większymi osiągnięciami i większą satysfakcją w tej dziedzinie. Większe znaczenie, jakie członkowie rodziny przywiązują do relacji rodzinnych, jest istotnie związane z wyższą jakością życia młodych dorosłych w dziedzinie Przynależność. Ponadto większa jakość życia dorosłych dzieci $\mathrm{z}$ niepełnosprawnością intelektualną $\mathrm{w}$ wymienionej dziedzinie współwystępuje z większą inicjatywą podejmowaną przez członków rodziny w celu poprawy warunków życia w dziedzinie Wsparcie innych osób oraz Kariera zawodowa i przygotowanie do kariery.

Większa satysfakcja rodziny ze zdrowia jej członków, ponadto większe możliwości poprawy swojej sytuacji finansowej oraz osiągnięć i satysfakcji w tej dziedzinie wiążą się istot- 
nie z wyższą jakością życia dorosłych dzieci w dziedzinie Stawanie się. Osoby z niepełnosprawnością intelektualną bardziej są zadowolone $\mathrm{z}$ angażowania się $\mathrm{w}$ sensowną aktywność oraz z rozwijania samego siebie, gdy rodzina przywiązuje większą wagę do relacji rodzinnych, przejawia więcej inicjatyw w tej dziedzinie, a także ma większe osiągnięcia i większą satysfakcję. Jakość życia dorosłych dzieci $\mathrm{z}$ niepełnosprawnością intelektualną $\mathrm{w}$ dziedzinie Stawanie się wiąże się z satysfakcją, jaką rodzina odczuwa w związku z realizacją wartości. Ponadto jakość życia osób w tej dziedzinie współwystępuje z większymi możliwościami i osiągnięciami w zakresie kariery i pracy członków rodziny oraz z osiągnięciami w zakresie spędzania wolnego czasu przez rodzinę, czyli stopniem zaangażowania członków rodziny $\mathrm{w}$ różne formy aktywności i rekreacji w wolnym czasie.

\section{DYSKUSJA}

Przedstawione badania poświęcone zostały jakości życia młodych dorosłych z lekką niepełnosprawnością intelektualną, jakości życia ich rodzin oraz poszukiwaniu zależności między tymi konstruktami. Skupiając się na charakterystyce profili wymienionych konstruktów, można zaobserwować następujące ich właściwości. Badane osoby z lekką niepełnosprawnością intelektualną wysoko oceniają jakość swego życia. Są zadowolone z ważnych spraw wiążących się $\mathrm{z}$ ich byciem, przystosowaniem się do otoczenia oraz dojrzewaniem i rozwijaniem się. Najmniej doceniły Przynależność wspólnotową, a najbardziej - Stawanie się praktyczne, czyli mniej są zadowolone z dostępu do różnych dóbr społecznych, wydarzeń kulturalnych, profesjonalnych usług. Można tłumaczyć to tym, iż respondenci są w większości mieszkańcami wsi lub małych miast, gdzie trudniej brać udział w wydarzeniach kulturalnych. Osoby mogą również bardziej pesymistycznie oceniać swoje szanse na ciekawą pracę, która to kwestia zawarta jest też w tej subdziedzinie. Największą satysfakcję przynoszą im sprawy najprostsze, tj. wykonywanie prac związanych z codzienną rzeczywistością.
Zadowolenie $\mathrm{z}$ niesienia pomocy innym może się wiązać $\mathrm{z}$ poczuciem bycia potrzebnym oraz z poczuciem skuteczności swojego działania. Ustosunkowując się do otrzymanych wyników, można dodać, iż stosunkowo wysoką jakość życia osób z niepełnosprawnością intelektualną stwierdzano także w niektórych innych badaniach (Zawiślak, 2011; Zasępa, 2011). Takie rezultaty można próbować zinterpretować, odwołując się do modelu opracowanego przez Olsena i Schobera (1993, za: Janssen, Schuengel, Stolk, 2005). Wskazują oni na to, iż nie zawsze musi być pełna zgodność między obiektywnymi warunkami życia a subiektywną ich oceną przez osoby niepełnosprawne intelektualnie. Możliwe sytuacje są następujące: 1) dobrostan (wellbeing): jest to subiektywne zadowolenie z warunków życia ocenionych przez obserwatorów jako dobre, 2) deprywacja (deprivation): jest to subiektywne niezadowolenie z warunków życia ocenionych przez obserwatorów jako złe, 3) dysonans (dissonance): brak subiektywnego zadowolenia z warunków życia ocenionych przez obserwatorów jako dobre, 4) adaptacja (adaptation): subiektywne zadowolenie $\mathrm{z}$ warunków życia ocenionych przez obserwatorów jako złe. Te różnice w ocenie mogą być uwarunkowane różnymi mechanizmami tłumaczącymi związek i oddziaływanie zmiennych psychospołecznych. Obiektywnie patrząc na warunki życia osób z niepełnosprawnością intelektualną, można zauważyć, iż są one trudniejsze niż osób $\mathrm{z}$ generalnej populacji. W wypadku badanej grupy około 1/3 młodych dorosłych żyje w rodzinach niepełnych. Wysokie rezultaty w subiektywnie ocenionej jakości życia mogą być wynikiem próby przystosowania się do rzeczywistości, cieszenia się każdą chwilą swojego życia i najdrobniejszymi sprawami, które są ich udziałem, a także szanowania rzeczy, które już posiadają. Być może młodzi dorośli, w perspektywie trudniejszej sytuacji w rodzinie pochodzenia, bardziej cenią zarówno to, co udało im się zdobyć w życiu, jak i bliskie relacje w rodzinie. Uzyskane wyniki mogą wskazywać na ważność wysiłków przystosowania się do różnych sytuacji życiowych oraz na dużą motywację do pokonywania trudności i prowadzenia godnego życia. 
Jakość życia rodziny badanych młodych dorosłych z lekką niepełnosprawnością intelektualną jest zróżnicowana. Najlepiej ocenione zostały takie dziedziny jakości życia rodziny, jak: Relacje rodzinne, Zdrowie członków rodziny i System wartości, a najniżej - Wsparcie innych osób, Pomoc społeczna i usługi specjalistyczne oraz Sytuacja finansowa. Podobny profil jakości życia rodziny uzyskano też w innych badaniach (Ajuwon, Brown, 2012; Brown i in., 2006; Čagran, Schmidt, Brown, 2011; Clark, Brown, Karrapaya, 2012; Neikrug, Roth, Judes, 2011; Rillotta i in., 2012; Svraka, Loga, Brown, 2011; Werner i in., 2009; Zasępa, Wołowicz, 2010). Choć w niektórych bogatych krajach, np. w Belgii, zadowolenie i osiągnięcia w zakresie sytuacji finansowej oraz pomocy usług specjalistycznych są wyższe (por. Steel i in., 2011). Subiektywna ocena jakości życia rodzin w dużym stopniu odzwierciedla obiektywne warunki ich życia.

Uzyskane wyniki badań wskazują na pewne zależności między jakością życia rodziny a subiektywnie ocenioną jakością życia młodych dorosłych z lekką niepełnosprawnością intelektualną. Stwierdzono, iż obiektywne warunki życia rodziny w zakresie sytuacji finansowej, relacji $\mathrm{w}$ rodzinie oraz wsparcia udzielanego przez krewnych są istotnie związane $\mathrm{z}$ subiektywnie ocenioną ogólną jakością życia młodych dorosłych oraz jakością życia w dziedzinie Przynależność i Stawanie się. Brak zależności między jakością życia rodziny a zadowoleniem młodych dorosłych z dziedziny Bycie, czyli z tego, kim są i jakie mają doświadczenia w sferze fizycznej, psychologicznej i duchowej, może wskazywać na potrzebę autonomii, na kształtowanie swojej tożsamości, poszukiwanie swojej drogi życiowej. Dziedziny jakości życia dorosłych dzieci związane z przystosowaniem się do otoczenia oraz rozwijaniem się w nim są bardziej związane $\mathrm{z}$ obiektywnymi warunkami życia rodziny. Lepsze warunki materialne rodziny mogą zapewniać bardziej odpowiednie środowisko do nauki, spędzania wolnego czasu, a także umożliwić w większym stopniu korzystanie $\mathrm{z}$ dóbr społeczno-kulturowych. Relacje w rodzinie pomagają młodym ludziom dobrze przystosować się do otoczenia oraz osiągać ważne cele życio- we i rozwijać się. Rodzina stanowi ważny wzorzec postępowania, przekazuje tradycje, normy moralne. Członkowie rodziny, przekazując sobie wzajemnie doświadczenia, uczą się, jak żyć i radzić sobie w życiu, w jaki sposób rozwiązywać problemy i konflikty. Źródłem wsparcia mogą być też krewni. Pomoc uzyskiwana od nich, a także miło spędzony czas mogą się przyczyniać do wzrostu poczucia bezpieczeństwa oraz satysfakcji z życia, być może też dumy, iż można liczyć na wsparcie dalszej rodziny.

Nieco więcej istotnych zależności stwierdzono między subiektywną jakością życia rodziny a jakością życia dorosłych dzieci z lekką niepełnosprawnością intelektualną. Lepszy stan zdrowia członków rodziny, w tym również młodego dorosłego z niepełnosprawnością intelektualną, może sprawiać, iż ma on więcej czasu na korzystanie z dóbr społeczno-kulturowych, na bardziej atrakcyjne formy spędzania czasu wolnego, może poświęcać więcej czasu na własny rozwój. W pewnych rodzinach stwierdzono schorzenia u członków rodziny. Dorosłe dzieci może więc przywiązują większe znaczenie do pomocy innym i jednocześnie odczuwają satysfakcję z tego, że mogą przynieść komuś ulgę w cierpieniu. Stwierdzono pozytywną istotną zależność między satysfakcją rodziny z sytuacji finansowej a jakością życia młodych dorosłych w dziedzinie Bycie. Zadowolenie członków rodziny z sytuacji finansowej może powodować, iż dzieci mniej martwią się o dom, o realizację ważnych celów i zaspokojenie często podstawowych potrzeb i tym samym mają lepsze samopoczucie oraz większą nadzieję na przyszłość. Lepsza sytuacja finansowa rodziny, a także istnienie większych możliwości jej poprawy mogą sprawiać, iż dzieci czują się bezpieczniej, planując swoje życie. Mogą mieć mniejsze poczucie obciążenia rodziny swoimi potrzebami i wydatkami związanymi z korzystaniem z dóbr społeczno-kulturowych, czasem wolnym i rozwojem swoich umiejętności. Stwierdzono następnie, iż im większe znaczenie ma rodzina dla wszystkich jej członków, tym lepiej dorosłe dzieci z niepełnosprawnością intelektualną oceniają jakość swego życia, a zwłaszcza w dziedzinie Przynależność i Stawanie się. Rodzina jest źródłem miłości, zaufania, poczucia bez- 
pieczeństwa, przynależności. Przyczynia się też do rozwoju i stawania się dziecka. Inicjatywy rodziny, aby uzyskać wsparcie emocjonalne lub praktyczne od innych, wiążą się w pozytywny sposób z jakością życia dzieci w dziedzinie Przynależność. Być może wynika to z tego, że dzieci doceniają wysiłki członków rodziny, lub też zadowolone są z kontaktów, które wiążą się z tymi inicjatywami. Uporządkowany system wartości rodziny, a zwłaszcza zadowolenie z niego, może sprzyjać nabywaniu umiejętności i doświadczeń życiowych przez dzieci, czyli wzmacniać jakość życia w dziedzinie Stawanie się. Większe przywiązywanie wagi przez rodziców do spraw kształcenia i dobrze wykonywanej pracy wiąże się z wyższą jakością życia dzieci w dziedzinie Przynależność i Stawanie się. Może to być związane $\mathrm{z}$ mobilizowaniem i wspomaganiem dzieci z niepełnosprawnością intelektualną, aby skończyły szkołę i zdobyły zawód. Lepiej wykształceni rodzice mogą być bardziej świadomi spraw związanych z niepełnosprawnością intelektualną i jej rehabilitacją, tym samym mogą lepiej pomagać dziecku. Osiągnięcia w zakresie czasu wolnego rodziny mogą w dużym stopniu pokrywać się z osiągnięciami dziecka w tym zakresie, gdyż bardzo często osoby z niepełnosprawnością intelektualną spędzają czas wolny $\mathrm{w}$ gronie rodziny.

Potwierdzenia uzyskanych wyników można do pewnego stopnia poszukiwać w rezultatach innych badań dotyczących czynników wpływających na jakość życia osób z niepełnosprawnością intelektualną. Na przykład Firkowska-Mankiewicz (2000) stwierdziła, iż na jakość życia tych osób duży wpływ ma środowisko, w którym żyją. Im bardziej jest ono korzystne, tym bardziej osoba jest samodzielna, potrafi lepiej decydować o swoim życiu, dokonywać poprawnych wyborów, aktywniej uczestniczyć w życiu społecznym, bardziej integrować się z innymi ludźmi. Większy poziom satysfakcji życiowej osób z niepełnosprawnością współwystępuje $z$ lepszą sytuacją finansową i większym zadowoleniem z warunków domowych (Lucas-Carrasco, Salwador-Carulla, 2012; Gregory $\mathrm{i}$ in., 2001). Badania (Campo i in., 1997; Lunsky, Benson, 2001; Miller, Chan, 2008) wykazały, iż silnym predyktorem jakości życia osób dorosłych z niepełnosprawnością intelektualną jest wsparcie społeczne. Wyniki badań potwierdzają, iż bardzo istotną rolę w życiu osób z niepełnosprawnością intelektualną odgrywa rodzina. Jest ona czynnikiem chroniącym przed rozwojem problemów zdrowia psychicznego (Zasępa, 2011) oraz stanowi ważny punkt odniesienia przy kształtowaniu poczucia sensu życia (Zasępa, 2015).

Uzyskane wyniki są nieco inne niż rezultaty badania przeprowadzonego przez Bertellego i współpracowników (2011), którzy stwierdzili zarówno pozytywne, jak i negatywne zależności między jakością życia rodziny a jakością życia dorosłych dzieci z niepełnosprawnością intelektualną. Pewnego wytłumaczenia tych różnic można próbować szukać w miejscu zamieszkania osób. W badaniu włoskim osoby z niepełnosprawnością intelektualną mieszkały w większości samodzielnie, a w badaniu polskim - wraz z rodziną pochodzenia. Poza tym włoskie badania dotyczyły osób starszych, 27-59-letnich, które miały więcej szans na bardziej samodzielne życie. Być może względy społeczno-kulturowe, różne warunki życia w Polsce i we Włoszech wpływają zarówno na jakość życia osób z niepełnosprawnością intelektualną, jak i na jakość życia rodziny oraz na inną postać zależności między nimi.

Ograniczeniem przedstawionych badań jest mała próba badawcza. W przyszłych badaniach warto powiększyć grupę badawczą i zróżnicować ją ze względu na niektóre parametry demograficzne, tj.: wiek życia, miejsce zamieszkania (miasto/wieś), sposób życia i mieszkania (samodzielne życie/ z rodziną pochodzenia), stan cywilny, stosunek do pracy. Ważne wydaje się też, aby w przyszłym badaniu jakość życia rodziny oceniały nie tylko matki, ale także pozostali członkowie rodziny. Warto również się zastanowić nad czynnikami zarówno wewnętrznymi, jak i zewnętrznymi, które mogą wpływać na jakość życia dorosłych osób z niepełnosprawnością intelektualną, na jakość życia rodziny oraz mogą być mediatorami lub moderatorami związku między tymi zmiennymi.

Literatura przedmiotu, a także doświadczenia kliniczne i obserwacje społeczne wskazują na to, iż życie rodziny, w której wzrastają 
osoby z niepełnosprawnością, jest trudniejsze i pod pewnymi względami różne $\mathrm{w}$ porównaniu $\mathrm{z}$ rodzinami, w których członkowie nie mają większych problemów zdrowotnych. Wydaje się, że powiązania między jakością życia rodziny a jakością życia młodych dorosłych z niepełnosprawnością intelektualną, którzy rozpoczynają na miarę swoich możliwości samodzielne życie, mogą mieć specyficzny charakter. Otrzymane wyniki badań potwierdzają znaczenie rodziny pochodzenia w życiu młodych dorosłych $\mathrm{z}$ niepełnosprawnością intelektualną i pozwalają wnioskować, że jest ona głównym źródłem wsparcia $\mathrm{w}$ dążeniu do zbudowania dorosłego życia. Doświadczenia wszystkich członków rodziny i jednocześnie rodziny jako całości oddziałują na osobę z niepełnosprawnością i wchodzą w interakcje z jej doświadczeniami.

\section{PRZYPIS}

1 Część badań została wykonana w ramach badań statutowych, dotacja APS (nr BST 09/07-II).

\section{BIBLIOGRAFIA}

Ajuwon P.M., Brown I. (2012), Family quality of life in Nigeria. Journal of Intellectual Disability Research, $56,61-70$.

Bailey D.B., McWilliam R.A., Darkes L.A., Hebbeler K., Simeonsson R.J., Spiker D., Wagner M. (1998), Family outcomes in early intervention: A framework for program evaluation and efficacy research. Exceptional Children, 64, 313-328.

Bertelli M., Bianco A., Rossi M., Scuticchio D., Brown I. (2011), Relationship between individual quality of life and family quality of life for people with intellectual disability living in Italy. Journal of Intellectual Disability Research, 55, 1136-1150.

Bramston P., Chipuer H., Pretty G. (2005), Conceptual principles of quality of life: An empirical exploration. Journal of Intellectual Disability Research, 49, 728-733.

Brown I., Anand S., Fung W.L.A., Isaacs B., Baum N. (2003), Family quality of life: Canadian results from an international study. Journal of Developmental and Physical Disabilities, 15, 207-230.

Brown R.I., Brown I. (2005), The application of quality of life. Journal of Intellectual Disability Research, 49, 718-727.

Brown R.I., MacAdam-Crisp J., Wang M., Iarocci G. (2006), Family quality of life when there is a child with a developmental disability. Journal of Policy and Practice in Intellectual Disabilities, 3, 238-245.

Brown R.I., Schalock R.L., Brown I. (2009), Concept of quality of life and its application to persons with intellectual disabilities and their families: Introduction and overview. Journal of Policy and Practice in Intellectual Disabilities, 6, 1-5.

Buntinx W.H., Schalock R.L. (2010), Models of disability, quality of life, and individualized supports: Implications for professional practice in intellectual disability. Journal of Policy and Practice in Intellectual Disabilities, 7, 283-294.

Čagran B., Schmidt M., Brown I. (2011), Assessment of the quality of life in families with children who have intellectual and developmental disabilities in Slovenia. Journal of Intellectual Disability Research, 55, 1164-1175.

Campo S.F., Sharpton W.R., Thompson B., Sexton D. (1997), Correlates of the quality of life of adults with severe or profound mental retardation. Mental Retardation, 35, 329-337.

Clark M., Brown R., Karrapaya R. (2012), An initial look at the quality of life of Malaysian families that include children with disabilities. Journal of Intellectual Disability Research, 56, 45-60.

Cramm J.M., Nieboer A.P. (2012), Longitudinal study of parents' impact on quality of life of children and young adults with intellectual disabilities. Journal of Applied Research in Intellectual Disabilities, 25, 20-28.

Cummins R.A. (2001), Living with support in the community: Predictors of satisfaction with life. Mental Retardation and Developmental Disabilities Research Reviews, 7, 99-104. 
Cummins R.A. (2005), Moving from the quality of life concept to a theory. Journal of Intellectual Disability Research, 49, 699-706.

Firkowska-Mankiewicz A. (2000), Badania nad jakością życia osób upośledzonych umysłowo. Społeczeństwo dla Wszystkich, 1, 4-6.

Gregory N., Robertson J., Kessissoglou S., Emerson E., Hatton C. (2001), Factors associated with expressed satisfaction among people with intellectual disability receiving residential supports. Journal of Intellectual Disability Research, 45, 279-291.

Harwas-Napierała B. (2009), Rodzina jako wartość a współczesność. W: B. Harwas-Napierała (red.), Rodzina jako wartość w rozwoju czlowieka, 11-24. Poznań: Wydawnictwo Naukowe UAM.

Head L.S., Abbeduto L. (2007), Recognizing the role of parents in developmental outcomes: A systems approach to evaluating the child with developmental disabilities. Mental Retardation and Developmental Disabilities Research Reviews, 13, 293-301.

Hoffman L., Marquis J., Poston D., Summers J.A., Turnbull A. (2006), Assessing family outcomes: psychometric evaluation of Beach Center Family Quality of Life Scale. Journal of Marriage and Family, 68, 1069-1083.

Isaacs B.J., Brown I., Brown R.I., Baum N., Myerscough T., Neikrug S., Roth D., Shearer J., Wang M. (2007), The international family quality of life project: Goals and description of a survey tool. Journal of Policy and Practice in Intellectual Disabilities, 4, 177-185.

Janssen C.G.C., Schuengel C., Stolk J. (2005), Perspectives on quality of life of people with intellectual disabilities: The interpretation of discrepancies between clients and caregivers. Quality of Life Research, 14, 57-69.

Keith K.D., Bonham G.S. (2005), The use of quality of life data at the organization and systems level. Journal of Intellectual Disability Research, 49, 799-805.

Lucas-Carrasco R., Salvador-Carulla L. (2012), Life satisfaction in person with intellectual disabilities. Research in Developmental Disabilities, 33, 1103-1109.

Lunsky Y., Benson B.A. (2001), Association between perceived social support and strain and positive and negative outcome for adults with mild intellectual disability. Journal of Intellectual Disability Research, $45,106-114$.

Miller S.M., Chan F. (2008), Predictors of life satisfaction in individuals with intellectual disabilities. Journal of Intellectual Disability Research, 52, 1039-1047.

McIntyre L.L., Kraemer B.R., Blacher J., Simmerman S. (2004), Quality of life for young adults with severe intellectual disability: Mothers' thoughts and reflections. Journal of Intellectual and Developmental Disability, 29, 131-146.

Neikrug S., Roth D., Judes J. (2011). Lives of quality in the face of challenge in Israel. Journal of Intellectual Disability Research, 55, 1176-1184.

Park J., Hoffman L., Marquis J., Turnbull A.P., Poston D., Mannan H., Wang M., Nelson L.L. (2003), Toward assessing family outcomes of service delivery: Validation of a family quality of life survey. Journal of Intellectual Disability Research, 47, 367-384.

Poston D.J., Turnbull A., Park J., Mannan H., Marquis J., Wang M. (2003), Family quality of life: A qualitative inquiry. Mental Retardation, 41, 313-328.

Raphael D., Brown I., Renwick R. (1999), Psychometric properties of the full and short versions of the Quality of Life Instrument Package: Results from the Ontario province-wide study. International Journal of Disability, Development and Education, 46, 157-168.

Rillotta F., Kirby N., Shearer J., Nettelbeck T. (2012), Family quality of life of Australian families with a member with an intellectual/developmental disability. Journal of Intellectual Disability Research, 56, 71-86.

Schalock R.L. (1994), Quality of life, quality enhancement, and quality assurance: Implications for program planning and evaluation in the field of mental retardation and developmental disabilities. Evaluation and Program Planning, 17, 121-131.

Schalock R.L. (2000), Three decades of quality of life. Focus on Autism and Other Developmental Disabilities, 15, 116-127.

Schalock R.L. (2004), The concept of quality of life: What we know and do not know. Journal of Intellectual Disability Research, 48, 203-216.

Schalock R.L., Brown I., Brown R., Cummins R.A., Felce D., Matikka L., Keith K.D., Parmenter T. (2002), Conceptualization, measurement, and application of quality of life for persons with intellectual disabilities: Report of an international panel of experts. Mental Retardation, 40, 457-470. 
Schalock R.L., Verdugo M.A., Jenaro Ch., Wang M., Wehmeyer M., Jiancheng X., Lachapelle Y. (2005), Cross-cultural study of quality of life indicators. American Journal on Mental Retardation, 110, 298-311.

Schwartz C., Rabinovitz S. (2003), Life satisfaction of people with intellectual disability living in community residences: Perceptions of the residents, their parents and staff members. Journal of Intellectual Disability Research, 47, 75-84.

Seltzer M.M., Krauss M.W. (1989), Ageing parents with adult mentally retarded children: Family risk factors and sources of support. American Journal on Mental Retardation, 94, 303-312.

Skinner D., Weisner T.S. (2007), Sociocultural studies of families of children with intellectual disabilities. Mental Retardation and Developmental Disabilities Research Reviews, 13, 302-312.

Steel R., Poppe L., Vandevelde S., Van Hove G., Claes C. (2011), Family quality of life in 25 Belgian families: Quantitative and qualitative exploration of social and professional support domains. Journal of Intellectual Disability Research, 55, 1123-1135.

Summers J.A., Poston D.J., Turnbull A.P., Marquis J., Hoffman L., Mannan H., Wang M. (2005), Conceptualizing and measuring family quality of life. Journal of Intellectual Disability Research, 49, 777-783.

Svraka E., Loga S., Brown I. (2011), Family quality of life: Adult school children with intellectual disabilities in Bosnia and Herzegovina. Journal of Intellectual Disability Research, 55, 1115-1122.

Wang M., Brown R. (2009), Family quality of life: A framework for policy and social service provisions to support families of children with disabilities. Journal of Family Social Work, 12, 144-167.

Werner S., Edwards M., Baum N., Brown I., Brown R.I., Isaacs B.J. (2009). Family quality of life among families with a member who has an intellectual disability: An exploratory examination of key domains and dimensions of the revised FQOL Survey. Journal of Intellectual Disability Research, 53, 501-511.

Zasępa E. (2015), Poczucie sensu życia młodych dorosłych z lekką niepełnosprawnością intelektualną. W: J. Głodkowska (red.), Personalistyczne ujęcie fenomenu niepetnosprawności, 193-209. Warszawa: Wydawnictwo Akademii Pedagogiki Specjalnej.

Zasępa E., Węglewska E. (2007), Obraz małżeństwa matek a występowanie u ich dzieci z lekką niepełnosprawnością intelektualną zaburzeń w zachowaniu. W: J. Patkiewicz (red.), Rola więzi w rozwoju dzieci i młodzieży niepetnosprawnej, 101-114. Wrocław: Polskie Towarzystwo Walki z Kalectwem.

Zasępa E., Wołowicz A. (2010), Jakość życia rodzin osób z niepetnosprawnościa intelektualna. Warszawa: Wydawnictwo Akademii Pedagogiki Specjalnej.

Zasępa E. (2011), Zaburzenia behawioralne i emocjonalne oraz ich korelaty u osób dorostych z lekka niepetnosprawnościa intelektualna. Warszawa: Wydawnictwo Akademii Pedagogiki Specjalnej.

Zasępa E. (2015), Poczucie sensu życia młodych dorosłych z lekką niepełnosprawności intelektualną. W: J. Głodkowska (red.), Personalistyczne ujęcie fenomenu niepetnosprawności, 193-209. Warszawa: Wydawnictwo Akademii Pedagogiki Specjalnej.

Zawiślak A. (2011), Jakość życia osób dorostych z niepetnosprawnościa intelektualną. Warszawa: Difin. 